\title{
Gastroparesis in Asia: An Area Still Unfamiliar to Asian Gastroenterologists
}

\author{
Kang Nyeong Lee \\ Department of Internal Medicine, Hanyang University College of Medicine, Seoul, Korea
}

\author{
Article: Knowledge, attitude, and practice survey of gastroparesis in Asia by Asian Neurogastroenterology and Motility \\ Association \\ Oshima T, Siah KTH, Kim YS, et al \\ (J Neurogastroenterol Motil 2021;27:46-54)
}

Are Asian doctors effectively diagnosing and managing patients with gastroparesis? Gastroparesis is a syndrome of delayed gastric emptying (GE) without accompanying evidence of mechanical obstruction in the gastrointestinal (GI) tract. ${ }^{1}$ The cardinal symptoms of gastroparesis include early satiety, postprandial fullness, nausea, vomiting, abdominal pain, and in severe cases, weight loss. ${ }^{2}$ Moreover, this syndrome has been associated with low quality of life and dissatisfaction regarding treatments. ${ }^{3}$ In Western studies, the prevalence in men and women has been reported to be 9.6 and 38 per 100000 persons, respectively. ${ }^{4} \mathrm{~A}$ study of Olmsted County residents estimated the incidence to be $1.8 \%$ according to regression models for GE rates. ${ }^{5}$ Nonetheless, there is a lack of research pertaining to Asian populations.

While the causes of gastroparesis are mainly idiopathic in nature, diabetic, iatrogenic (such as medication-induced), postsurgical, and neurologic factors can also be responsible. ${ }^{2}$ The pathophysiology is based on the presence of abnormalities in cells or tissues normally associated with physiological functions pertaining to GE, such as gastric pacemaker cells, intrinsic and extrinsic nerves, smooth muscle, and immune cells. Previous studies on patients with gastroparesis have reported disruption of the smooth muscle cells, interstitial cells of Cajal (ICC), and platelet-derived growth factor receptor $\alpha$-positive (PDGFR $\alpha+$ ) cells syncytium (SIP syncytium), a gastric pacemaker composed of smooth muscle cells, ICC, and PDGFR $\alpha+$ cells, involving a reduction in ICC and PDGFR $\alpha+$ cells in diabetic and idiopathic gastroparesis, respectively. ${ }^{6,7}$ Histologic or biochemical changes in the intrinsic and extrinsic nerves, as well as in the smooth muscle have been reported in both human and animal studies. Additionally, macrophagesdriven immune and inflammatory changes, such as a loss of antiinflammatory macrophages in the stomach antrum, were implicated in gastroparesis due to their association with ICC loss in gastroparesis patients, as determined by both GE tests and the Gastroparesis Cardinal Symptom Index. ${ }^{8}$

Gastroparesis may overlap with functional GI disorders in terms of pathophysiology, symptomatology, and treatment. ${ }^{9}$ Symptoms of nausea, vomiting, early satiety, postprandial fullness, abdominal pain in gastroparesis are very similar to those of functional dyspepsia (FD). Even the pathophysiologic mechanism of delayed $\mathrm{GE}$ in gastroparesis resembles that of FD: some FD patients show delayed GE; rapid GE; impaired fundic accommodation; and hypersensitivity to acid, lipid, or luminal distention. ${ }^{9,10}$ Gastropare-

Received: November 25, 2020 Revised: None Accepted: December 6, 2020

(.) This is an Open Access article distributed under the terms of the Creative Commons Attribution Non-Commercial License (http://creativecommons. org/licenses/by-nc/4.0) which permits unrestricted non-commercial use, distribution, and reproduction in any medium, provided the original work is properly cited.

${ }^{*}$ Correspondence: Kang Nyeong Lee, MD, PhD Department of Internal Medicine, Hanyang University College of Medicine, 222 Wangsimni-ro, Seoungdong-gu, Seoul 04763, Korea

Tel: +82-2-2290-8339; Fax: +82-2-2290-8314, E-mail: leekn@hanyang.ac.kr 
sis should also be differentiated from other functional GI diseases having upper abdominal symptoms including cyclic vomiting syndrome and rumination syndrome. ${ }^{11}$ Furthermore, GE scintigraphy (GES) is the current diagnostic gold standard, but its implementation differs between institutions.

The paucity of research on gastroparesis in Asian populations, which the authors attribute to issues of lack of interest and underdiagnosis, provides the backdrop for this important survey by the Asian Neurogastroenterology and Motility Association (ANMA). In this issue of the Journal of Neurogastroenterology and Motility, the results of the ANMA survey seek to shed light not only on the current understanding of gastroparesis in Asia, but also expectations of future improvements in the evaluation and management of the syndrome in this population. ${ }^{12}$ The investigators conducted the survey using questionnaires that assessed the knowledge, attitude, and practices of Asian doctors with respect to gastroparesis. The number of questions pertaining to knowledge, attitude, and practices was 6,2 , and 7 , respectively. The questionnaire was developed through a literature review by 3 experts with more than 15 years of experience each in GI motility disorders who were selected by the ANMA research committee. The participants of this survey included 490 doctors (mostly gastroenterologists, $81.2 \%$ ) from various Asian countries, including Bangladesh, China, Hong Kong, Indonesia, Japan, Malaysia, Myanmar, the Philippines, Singapore, South Korea, Taiwan, Thailand, and Vietnam.

The survey results showed that the knowledge concerning the definition and diagnostic gold standards of gastroparesis was weak (correct in $24.2 \%$ and $54.2 \%$ of the respondents, respectively). In addition, the proportions of cases diagnosed with diabetic gastroparesis or FD with delayed GE were low, and the medications given during gastroparesis mostly consisted of antiemetics and prokinetics. In terms of attitude, more than $80 \%$ of the respondents considered gastroparesis to be very or quite important, regardless of the availability of GES tests. The authors found that the availability of GES was related to the reason for the lack of interest in gastroparesis. Specifically, the lack of interest was most commonly due to treatment ineffectiveness ( $41.5 \%$ of the respondents) among the doctors in institutions where GES was available, whereas the lack of reliable diagnostic tests (46.8\%) was the primary reason for the lack of interest among the institutions without access to GES. Regarding the practices of gastroparesis, more than $78 \%$ of the respondents stated that the number of patients diagnosed with gastroparesis at their institutions in the previous year was lower than 5 . There were differences in terms of the diagnostic criteria used for both delayed gastric retention by GES and the time frame of GES in addition to the test meals.

In light of the above, knowledge of gastroparesis needs to be widely disseminated throughout Asia. Moreover, the interest of Asian doctors in gastroparesis should be increased along with the availability of the diagnostic testing, and standardized protocols and meals during the testing should be implemented. Lastly, treatment efficacy must improve. An increased understanding of the cellular and molecular events in gastroparesis during the past decade has enabled clearer associations to be established between various clinical presentations, causes and GE status, thereby giving rise to significant diagnostic and therapeutic developments. ${ }^{13}$ The nonstandardized approach of GES may be replaced by noninvasive alternatives such as the $13 \mathrm{C} \mathrm{GE}$ breath test ${ }^{14}$ and the wireless motility capsule. ${ }^{15}$ In addition, clinical trials have demonstrated the efficacy of newer antiemetic agents such as the tachykinin receptor antagonist, tradipitant ${ }^{16}$ and gastroenterokinetics such as the selective ghrelin agonist, relamorelin. ${ }^{17}$ Furthermore, refractory pyloric dysfunction in gastroparesis has been successfully managed using botulinum toxin injection around the pylorus ${ }^{18}$ and gastric per-oral endoscopic pyloromyotomy. ${ }^{19}$ In order to increase diagnostic accuracy and treatment efficacy and also to improve the lack of interest in gastroparesis across Asia, we should try to identify its specific biomarkers by further research in Asia. Obviously, this ANMA survey has taken the meaningful step to Asian research of gastroparesis.

\section{Financial support: None.}

\section{Conflicts of interest: None.}

\section{References}

1. Parkman HP, Hasler WL, Fisher RS, American Gastroenterological Association. American Gastroenterological Association medical position statement: diagnosis and treatment of gastroparesis. Gastroenterology 2004;127:1589-1591.

2. Soykan I, Sivri B, Sarosiek I, Kiernan B, McCallum RW. Demography, clinical characteristics, psychological and abuse profiles, treatment, and long-term follow-up of patients with gastroparesis. Dig Dis Sci 1998;43:2398-2404.

3. Yu D, Ramsey FV, Norton WF, et al. The burdens, concerns, and quality of gife of patients with gastroparesis. Dig Dis Sci 2017;62:879-893.

4. Jung HK, Choung RS, Locke GR 3rd, et al. The incidence, prevalence, and outcomes of patients with gastroparesis in Olmsted County, Minnesota, from 1996 to 2006. Gastroenterology 2009;136:1225-1233.

5. Rey E, Choung RS, Schleck CD, Zinsmeister AR, Talley NJ, Locke GR 3rd. Prevalence of hidden gastroparesis in the community: the gastroparesis “iceberg”. J Neurogastroenterol Motil 2012;18:34-42. 
6. Bernard CE, Gibbons SJ, Mann IS, et al. Association of low numbers of CD206-positive cells with loss of ICC in the gastric body of patients with diabetic gastroparesis. Neurogastroenterol Motil 2014;26:1275-1284.

7. Herring BP, Hoggatt AM, Gupta A, et al. Idiopathic gastroparesis is associated with specific transcriptional changes in the gastric muscularis externa. Neurogastroenterol Motil 2018;30:e13230.

8. Grover M, Bernard CE, Pasricha PJ, et al. Diabetic and idiopathic gastroparesis is associated with loss of CD206-positive macrophages in the gastric antrum. Neurogastroenterol Motil Published Online First: 9 Jan 2017. doi: $10.1111 / \mathrm{nmo} .13018$.

9. Kim BJ, Kuo B. Gastroparesis and functional dyspepsia: a blurring distinction of pathophysiology and treatment. J Neurogastroenterol Motil 2019;25:27-35.

10. Quartero AO, de Wit NJ, Lodder AC, Numans ME, Smout AJ, Hoes AW. Disturbed solid-phase GE in functional dyspepsia: a meta-analysis. Dig Dis Sci 1998;43:2028-2033.

11. Stanghellini V, Chan FK, Hasler WL, et al. Gastroduodenal disorders. Gastroenterology 2016;150:1380-1392.

12. Oshima T, Siah KTH, Kim YS, et al. Knowledge, attitude, and practice survey of gastroparesis in Asia by Asian Neurogastroenterology and Motility Association. J Neurogastroenterol Motil 2021;27:46-54.

13. Grover M, Farrugia G, Stanghellini V. Gastroparesis: a turning point in understanding and treatment. Gut 2019;68:2238-2250.

14. Szarka LA, Camilleri M, Vella A, et al. A stable isotope breath test with a standard meal for abnormal GE of solids in the clinic and in research. Clin Gastroenterol Hepatol 2008;6:635-643, e1.

15. Lee AA, Rao S, Nguyen LA, et al. Validation of diagnostic and performance characteristics of the wireless motility capsule in patients with suspected gastroparesis. Clin Gastroenterol Hepatol 2019;17:1770-1779, e2.

16. Carlin JL, Lieberman VR, Dahal A, et al. Efficacy and safety of tradipitant in patients with diabetic and idiopathic gastroparesis in a randomized, placebo-controlled trial. Gastroenterology Published Online First: $18 \mathrm{Jul}$ 2020. doi: 10.1053/j.gastro.2020.07.029.

17. Camilleri M, McCallum RW, Tack J, Spence SC, Gottesdiener K, Fiedorek FT. Efficacy and safety of relamorelin in diabetics with symptoms of gastroparesis: a randomized, placebo-controlled study. Gastroenterology 2017;153:1240-1250, e2.

18. Reichenbach ZW, Stanek S, Patel S, et al. Botulinum toxin A improves symptoms of gastroparesis. Dig Dis Sci 2020;65:1396-1404.

19. Gonzalez JM, Lestelle V, Benezech A, et al. Gastric per-oral endoscopic myotomy with antropyloromyotomy in the treatment of refractory gastroparesis: clinical experience with follow-up and scintigraphic evaluation (with video). Gastrointest Endosc 2017;85:132-139. 